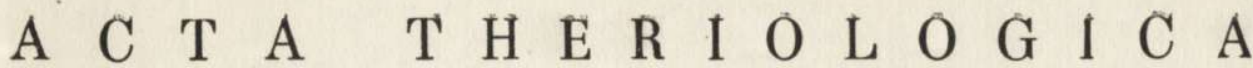 \\ VOL. XIII, 5: $65-71$.

\section{Caloric Value and Chemical Composition of the Body of the European Hare}

[With 3 Tables]

\begin{abstract}
Examination was made of the caloric value and chemical composition of the bodies of 20 individuals of Lepus europaeus, P a ll a s 1778, shot in December 1966 in central Poland. It was found that the caloric value of biomass of winter hares is $1.874 \mathrm{kcal} / \mathrm{g}$ and is greater than that given for small mammals. Water $67.04 \%$ ), ash in dry $(12.38 \%$ ) and fresh mass $\left(4.08^{\circ} \%\right)$ and total protein contents $(64.01 \%$ in dry and $11.10 \%$ in fresh tissue) are similar to the values of these indices observed in rodents, whereas the bodies of the hares examined contain slightly more fat in comparison with small mammals $(19.41 \%$ in dry and $6.40 \%$ in fresh mass), the caloric value of which is almost $9 \mathrm{kcal} / \mathrm{g}$.
\end{abstract}

\section{INTRODUCTION}

The caloric values of the body of animals provide information of great importance to bio-energy investigations. It is for this reason that a relatively large amount of data on calorimetric measurements of the bodies of mammals can be found in literature. In the majority of cases, however, these are incidental data obtained from burning only a small number of individuals (G olle y, 1961; Slobodkin, 1962; Davis \& Golley, 1963), but studies based on extensive material and taking into consideration seasonal variations in these indices (Gó$\mathrm{recki}, 1965$ ) or their changes in the postnatal development of animals ( $\mathrm{M} \mathrm{y} \mathrm{ch} \mathrm{a}$ \& W a k k wa, 1968) have already appeared.

Investigations of the chemical composition of mammals' bodies were first made some time ago in respect of both laboratory (A shworth \& Cow g il, 1938; P ace \& R athbun, 1945; Fowler, 1958; B a iley et al., 1960) and wild animals (Pitts, 1960; 1962; J a mes on \& M e a d, 1964; H a y w a r d, 1965). This question, which is of importance inter alia from the aspect of heat production and energy economy of the organism, has now been elaborated from both the methodical and theoretical standpoints (B r o ž e k, 1961; B r ož e k \& H en s che l, 1961; M i t c hell, 1962; He n r y, 1965).

Some information on the caloric value and chemical composition of the body of Lepus europaeus Palla s, 1778 is given by Tilg ner $(1949 ; 1950 ; 1953 ; 1953 \mathrm{a})$, 
but these data refer to hare meat only. The hare is a very important animal from the economic point of view and a knowledge of its energy potential is essential to the intensive ecological studies being made of this mammal. On this account it was decided to investigate the chemical composition and caloric value of the body and some of the internal organs of this species.

\section{MATERIAL AND METHODS}

The chemical composition and caloric value of the body and some of the organs of $L$. europaeus were determined by examining 20 individuals (10 $\sigma^{\top} \sigma^{\top}$ and 10 O $O$ ) of this species. All the animals used for the examination were obtained from central Poland and had been shot during the first half of December 1966. Their average body weight was $4.0 \mathrm{~kg}$. 10 hares were first cut up into small pieces, then passed through an electric mincer. In order to ensure that the material was thoroughly minced and mixed each hare was passed through the mincer 3 times, using an increasingly fine chopper and mixing the mince thoroughly each time. Five samples were taken from each of the hares prepared in this way. After dissecting the remaining 10 animals, the heart, lungs, kidneys, stomach, liver, brain, part of the muscles of the back of the neck and upper leg, the fat surrounding the kidneys and the skin were excised for separate investigation.

All the samples were first carefully weighed, then dried in a vacuum oven at a temperature of $65-70^{\circ} \mathrm{C}$ with $\mathrm{CaCl} 2$ present. After the material had been dried it was weighed for the second time, ascertaining in this way the water content of the fresh body and organs of the hare. Caloric value was determined by burning samples $1.0-1.3 \mathrm{~g}$ in size in a Berthelot system $\mathrm{KL}-3$ calorimeter. The ash content in the samples examined was determined at the same time from the material burnt in the calorimeter. The data obtained made it possible to calculate the caloric value of $1 \mathrm{~g}$ of dry mass, $1 \mathrm{~g}$ of dry mass without ash and also $1 \mathrm{~g}$ of biomass (that is, fresh mass) of the hare.

Examination was made of the fat and protein contents in the bodies of hares by means of analysing part of the material from each sample prepared for burning in the calorimeter, in order to determine the caloric value of the whole body of $L$. europaeus. The amount of fat was determined by the Puzanow method, also known as the Hannon and Badun or Besson method ( $\mathrm{Kr}$ a u ze et al., 1966). It consists in double extraction (by steam and condensed solvent) by petroleum ether with the addition of ethyl alcohol, of material placed in a glass vessel with a foam glass bottom. The required time for adequate extraction had been determined earlier on by experiment as three hours. Longer extraction did not result in any differences in the weight of the sample. The amount of protein in the body of a hare was defined by the Kjeldahl method, mineralizing the material on electric firebrick stoves and determining nitrogen in a Parnas-Wagner apparatus.

All results were statistically elaborated, calculating the mean values and describing them by confidence intervals based on the variable $t$. Mean values calculated for males and females were compared by means of the $t$-Student test. No statistically significant differences were found in any of the cases.

\section{DISCUSSION OF RESULTS}

The caloric values of the whole body are given in table 1 , and of the different organs of $L$. europaeus in table 2 . The results obtained justify 
the statement that the caloric values of the body of the hare are very high in comparison with other wild mammals. Caloric values of mammal tissues are generally very similar and therefore G o ll e y (1961) suggests accepting the mean energy value of $1 \mathrm{~g}$ of biomass of the body of wild mammals as $1.4 \mathrm{kcal} / \mathrm{g}$ for ecological investigations. G ó r e c k i (1965), on the basis of his comprehensive examinations of 5 species of rodents and insectivores, postulates raising this index to $1.5 \mathrm{kcal} / \mathrm{g}$. The caloric value of $1 \mathrm{~g}$ of biomass of the European hare is higher than the

Table 1.

Mean ( \pm S. D.) caloric values of the European hare body.

\begin{tabular}{|c|c|c|c|c|}
\hline $\begin{array}{c}\text { No. of } \\
\text { animals }\end{array}$ & $\begin{array}{c}\text { No. of } \\
\text { samples }\end{array}$ & $\begin{array}{c}\text { Dry mass } \\
(\mathrm{cal} / \mathrm{g})\end{array}$ & $\begin{array}{c}\text { Ash-free mass } \\
(\mathrm{cal} / \mathrm{g})\end{array}$ & $\begin{array}{c}\text { Biomass } \\
\text { (cal/g) }\end{array}$ \\
\hline 10 & 50 & $5684.82 \pm 100.52$ & $6492.60 \pm 85.20$ & $1873.85 \pm 32.0$ \\
\hline
\end{tabular}

Table 2.

Mean water and ash contents and caloric values of some internal organs of European hare.

\begin{tabular}{|l|c|c|c|c|}
\hline \multicolumn{1}{|c|}{ Organ } & $\begin{array}{c}\text { Water } \\
\text { content }\end{array}$ & $\begin{array}{c}\text { Ash content } \\
\text { (in per cent } \\
\text { of dry mass) }\end{array}$ & $\begin{array}{c}\text { Caloric value } \\
\text { (cal/g) } \\
\text { of dry mass }\end{array}$ & $\begin{array}{c}\text { Caloric value } \\
\text { (cal/g) } \\
\text { of } \begin{array}{c}\text { ash-free mass } \\
\text { mas }\end{array}\end{array}$ \\
\hline Heart & $75.93 \pm 0.76$ & $4.03 \pm 0.34$ & $5944.70 \pm 263.96$ & $6188.11 \pm 268.69$ \\
Lungs & $75.68 \pm 1.15$ & $4.03 \pm 0.79$ & $5773.05 \pm 97.16$ & $6018.51 \pm 113.44$ \\
Liver & $73.06 \pm 2.74$ & $3.86 \pm 0.69$ & $5754.74 \pm 187.20$ & $5986.08 \pm 110.10$ \\
Kidneys & $75.47 \pm 2.68$ & $5.01 \pm 0.27$ & $5760.54 \pm 304.73$ & $6075.06 \pm 213.19$ \\
Stomach & $80.93 \pm 1.27$ & $3.81 \pm 0.59$ & $5867.13 \pm 194.32$ & $6104.93 \pm 208.13$ \\
Muscle (neck) & $73.37 \pm 1.60$ & $3.31 \pm 0.48$ & $5620.52 \pm 168.79$ & $5814.40 \pm 192.40$ \\
Muscle (hind legs) & $72.51 \pm 1.62$ & $3.68 \pm 0.35$ & $5601.32 \pm 120.69$ & $5815.78 \pm 141.71$ \\
Brain & $74.69 \pm 2.81$ & $5.99 \pm 0.81$ & $6921.47 \pm 162.21$ & $7553.27 \pm 178.93$ \\
Adrenal fat & - & $0.95 \pm 0.57$ & $8868.85 \pm 185.67$ & $8952.78 \pm 143.68$ \\
Skin & - & $1.99 \pm 0.46$ & $4960.57 \pm 168.42$ & $5063.57 \pm 183.02$ \\
\hline
\end{tabular}

values given by these authors, being $1.874 \mathrm{kcal} / \mathrm{g}$. Comparison of the data obtained for the hare and G ó r e c k i's data (1965) shows that the caloricity of $1 \mathrm{~g}$ of dry mass of L. europaeus is almost 1000 cal. higher than the analogical value calculated for rodents caught in the winter. It is true that Go recki (1965) found that there are seasonal variations in the value of this index in the species of animals he investigated, but even the maximum caloric value of dry mass of summer, adipose Apodemus agrarius (P alla s, 1771) is almost $300 \mathrm{cal} / \mathrm{g}$ lower than that of the hare. 
Tilgner $(1949 ; 1950 ; 1953)$ gives some information on the caloric value of the hare but they refer only to hare meat. The author states that the caloric value of $100 \mathrm{~g}$ pure hare meat is about $100 \mathrm{kcal}$, but calculations made on the basis of burnt muscles of the upper leg and back of the neck (Table 2) point to the energy value of the meat of this mammal being higher. The caloric value of $100 \mathrm{~g}$ of meat of the animals examined is about $146 \mathrm{kcal}$, whereas $\mathrm{Ti} \operatorname{lg~n}$ e r $(1949 ; 1950 ; 1953)$ gives $136 \mathrm{kcal}$ for roasted hare meat, that is, meat containing far less water.

The remaining data describing the caloricity of some of the organs of $L$. europaeus (Table 2) cannot unfortunately be compared with the corresponding indices for other species of wild mammals, as there is no relevant information on this subject in the literature to which I had access. The caloricity of the majority of the organs of the hare which I examined is very similar, being approximately $5.6-5.7 \mathrm{kcal} / \mathrm{g}$ of dry mass. The myocardium is distinguished by a higher energy value (5.9 $\mathrm{kcal} / \mathrm{g}$ ) while that of the brain (6.9) is even higher but the caloricity index of the skin integument is lowest (about $5.0 \mathrm{kcal} / \mathrm{g}$ ).

Table 3.

Gross body composition of Lepus europaeus.

\begin{tabular}{|c|c|c|c|c|c|c|}
\hline \multirow{2}{*}{$\begin{array}{c}\text { No. of } \\
\text { animals }\end{array}$} & $\begin{array}{c}\text { No. of } \\
\text { samples }\end{array}$ & $\begin{array}{c}\text { Water } \\
\text { content } \\
\text { (in per cent) }\end{array}$ & $\begin{array}{c}\text { Dry mass } \\
\text { content } \\
\text { (in per cent) }\end{array}$ & \multicolumn{2}{c|}{ Dry mass composition (in per cent) } \\
\cline { 5 - 7 } & & Ash & Fat & Protein \\
\hline 10 & 50 & $67.04 \pm 0.59$ & $32.96 \pm 0.31$ & $12.38 \pm 1.00$ & $19.41 \pm 1.71$ & $64.01 \pm 2.99$ \\
\hline
\end{tabular}

Data describing the chemical composition in percentages of body of winter hares are given in table 3 . When these results are calculated for fresh mass we find that the body of a $4 \mathrm{~kg}$ hare contains $2681.6 \mathrm{~g}$ of water $(67.04 \%), 163.2 \mathrm{~g}$ of ash $(4.08 \%), 255.9 \mathrm{~g}$ of fat $(6.40 \%)$ and $844.2 \mathrm{~g}$ of protein $(21.1 \%)$. Unidentified components form only $1.38 \%$ of the body weight of the animals examined.

Water content in the body of $L$. europaeus is very similar to the amount of water observed by Gór e cki (1965) in 5 species of small European mammals, and by $\mathrm{H}$ a y ward (1965) in 6 geographical American breeds of Peromyscus. The percentage of ash content in the dry mass of hare is also very similar to the value obtained by G ó re ck i (1965) for rodents. Fat content in the body of the animals examined is relatively high, forming $19.5 \%$ of dry mass, that is, $6.4 \%$ of the fresh body of a hare. This fat has at the same time a high caloric value of approximately $9 \mathrm{kcal} / \mathrm{g}$. This large amount of highly caloric fat may account for the high value of the 
caloric equivalent of $1 \mathrm{~g}$ of biomass of the animals examined. This is probably a store of fat accumulated earlier and used to produce heat during the winter conditions unfavourable to this species. This is indicated by its distribution which is almost entirely confined to the kidneys. The fat content observed in the body of $L$. europaeus is slightly greater than that given by $\mathrm{H}$ a y ward (1965) for Peromyscus and far higher than the values obtained earlier by $\mathrm{T}$ ilg $\mathrm{n}$ e r $(1949 ; 1950)$ when examining the bodies of hares. Conversely the percentage of protein content in the body of whole hares $(21.1 \%)$ is slightly lower than that observed by Tilgner $(1949 ; 1950)$ in the bodies of hares. On the other hand the amount of protein obtained in the present investigations in the body of $L$. europaeus is very similar to the data obtained by $\mathrm{Pac}$ e \& $\mathrm{R}$ a thbun (1945), Mitchell (1962) and Hayward (1965) for both wild and laboratory animals.

\section{REFERENCES}

1. Ashworth U. S. \& Cowgill G. R., 1938: Body composition as a factor governing the basal heat production and the endogenous nitrogen excretion. J. Nutr., 15: 73-81.

2. B a il e y C. B., Kitts W. D. \& W o o d A. J., 1960: Changes in the gross chemical composition of the mouse during growth in relation to the assessment of physiological age. Canad. J. Anim. Sci., 40: 143-155.

3. B r o ž e k J., 1961: Body composition. Science, 134: 920-930.

4. Brožek J. \& H en s chel A. (ed.), 1961: Techniques for measuring body composition. Nat. Acad. Sci. - Nat. Res. Council: Washington D. C.

5. Davis D. E. \& Golle y F. B., 1963: Principles in mammalogy. Reinhold Publ. Corp., 1-335. New York.

6. F owler R. E., 1958: The growth and carcass composition of strains of mice selected for large and small body size. J. Agric. Sci., 51: 137-148.

7. Golle y F. B., 1961: Energy values of ecological materials. Ecology, 42: 581584.

8. Górecki A.; 1965: Energy values of body in small mammals. Acta theriol., 10: $333-352$.

9. Ha y w a r d J. S., 1965: The gross body composition of six geographic races of Peromyscus. Canad. J. Zool., 43: 297-308.

10. Henry K. M., 1965: A comparison of biological methods with rats for determining the nutrive value of proteins. Brit. J. Nutr., 19: 125-135.

11. J a mes on E. W. \& Me a d R. A., 1964: Seasonal changes in body fat, water and basic weight in Citellus lateralis, Eutamias speciosus and E. amoenus. J. Mammal., 45: 359-365.

12. Krauze S., Bożyk Z. \& Piekarski L., 1966: Podręcznik laboratoryjny analityka żywnościowego. Państw. Zakł. Wyd. Lek.: 1-588. Warszawa.

13. Mitchel1 H. H., 1962: Comparative nutrition of man and domestic animals. Academic Press, vol. 1: 1-194. New York.

14. Myrcha A. \& Walkowa W., 1968: Zmiany wartości kalorycznej ciała w rozwoju postnatalnym białych myszy. Acta theriol., (in print). 
15. P a ce N. \& R a thbun E. N., 1945: Studies on body composition. 3. The body water and chemically combined nitrogen content in relation to fat content. J. Biol. Chem., 158: 685-691.

16. Pitts G. C., 1960: A study of gross body composition of small Alaskan mammals as compared with those from the temperature zone. Arctic Aeromed. Lab. Tech. Dept., 57: 1-13.

17. P it s G. C., 1962: Density and body composition of the lean compartment and its relationship to fatness. Amer. J. Physiol., 202: 445-452.

18. Slobodkin L. B., Energy in animal ecology. In: Cragg J. B. ed.: Advances in ecological research, 1: 69-1014 Academic Press. London - New York.

19. Tilgner D. J., 1949: Wartość przetwórcza zajęcy. Łowiec pol., 51: 19-22.

20. Tilgn er D. J., 1950: Wydajność i selekcja zajęcy. Łowiec pol., 52: 12-16.

21. Tilgner D. J., 1953: Ilość i jakość zająca gdańskiego. Łowiec pol., 55: 72-73.

22. Tilgner D. J., 1953a: Produktivität und Qualität der Hasenstrecken. Z. Jagdwiss., 1: 75-77.

Received, November 20, 1967.

Polish Academy of Sciences,

Institute of Ecology,

Warszawa, ul. Nowy Swiat 72.

Andrzej MYRCHA

WARTOSC KALORYCZNA I SKŁAD CHEMICZNY CIAŁA ZAJĄCA SZARAKA

\section{Streszczenie}

Zbadano wartość kaloryczną i skład chemiczny ciała 20 osobników Lepus europaeus Pallas 1778, odstrzelonych w grudniu 1966 r. na terenie Polski Centralnej. Stwierdzono, że wartość kaloryczna biomasy zajęcy zimowych wynosi $1,874 \mathrm{kcal} / \mathrm{g}$ i jest większa od podawanej dla drobnych ssaków. Zawartość wody $(67,04 \%)$, popiołu w suchej $(12,38 \%)$ i świeżej masie $(4,08 \%)$ oraz białka calkowitego $(64,01 \%$ w suchej i $21,10 \%$ w świeżej tkance) są podobne do wartości tych wskaźników obserwowanych u gryzoni. Ciało badanych zajẹcy zawiera natomiast nieco więcej, w porównaniu z drobnymi ssakami, tłuszczu $(19,41 \% \mathrm{w}$ suchej i $6,40 \% \mathrm{w}$ świieżej masie), którego wartość kaloryczna wynosi prawie $9 \mathrm{kcal} / \mathrm{g}$. 